\title{
POWER, IDENTITY, AND CULTURE IN INTERNATIONAL STUDENTS' PERCEPTIONS OF ACADEMIC WRITING
}

\section{PODER, IDENTIDADE E CULTURA NA PERCEPÇÃO DE ESCRITA ACADÊMICA DE ESTUDANTES INTERNACIONAIS}

\section{Jessica Garska* \\ Sarah O'Brien **}

\begin{abstract}
Issues surrounding English for Academic Purposes (EAP) and its use by English as an additional language (EAL) students in higher education have become increasingly significant in recent years, fueled both by increased international student mobility and increased linguistic and cultural diversity within and outside of the student body. As well as posing language-related challenges, the transfer of EAL students to an English-speaking foreign university also demands the negotiation of new university expectations, channeled through a new cultural environment. While Academic Literacies research has identified that concepts such as power, identity, and culture play a role in academic writing, students' own perceptions remain relatively unexplored. Consequently, this study analyzes the ways in which EAL students articulate their relationship with academic writing at a tertiary institution in Ireland. Data for this study were gathered through questionnaires and interviews and analyzed through discourse analysis through a critical lens. The findings suggest that while participants generally positively reflect on their ability to negotiate academic writing through the English language, there is nonetheless a high level of conflict between dominant linguistic norms and the students' expression of their identity and culture.
\end{abstract}

Keywords: english for academic purposes; academic literacies; cultural theory.

\section{RESUMO}

Questões em torno do inglês para fins acadêmicos e seu uso por falantes de inglês como idioma adicional (EAL) no ensino superior têm se tornado cada vez mais significativas nos últimos anos, impulsionadas pelo aumento da mobilidade internacional de estudantes e pelo aumento da diversidade cultural e linguística dentro e fora do corpo discente. Além de apresentar desafios relacionados à linguagem, a transferência de estudantes do EAL para uma universidade estrangeira de língua inglesa também exige a negociação de novas expectativas da universidade, canalizadas por meio de um novo ambiente cultural. Enquanto a pesquisa de letramentos acadêmicos identificou que conceitos como poder, identidade e cultura desempenham um papel na escrita acadêmica, as percepções dos próprios alunos permanecem relativamente inexploradas. Consequentemente, este estudo analisa as maneiras pelas quais os estudantes do EAL articulam sua relação com a escrita acadêmica

\footnotetext{
* Trinity College Dublin, Ireland. garskaj@tcd.ie

** Trinity College Dublin, Ireland. sarah.obrien@tcd.ie
} 
em uma instituição terciária na Irlanda. Os dados para este estudo foram coletados por meio de questionários e entrevistas, analisados por meio da análise do discurso por meio de uma lente crítica. As descobertas sugerem que, embora os participantes geralmente reflitam positivamente sobre sua capacidade de negociar a escrita acadêmica através da língua inglesa, existe um alto nível de conflito entre as normas lingüísticas dominantes e a expressão de identidade e cultura dos alunos.

Palavras-chaves: inglês para fins acadêmicos; letramentos acadêmicos; teoria cultural.

\section{INTRODUCTION}

International student mobility has increased the cultural, ethnic, and linguistic heterogeneity of the student population, exposing foreign students to new expectations and presenting specific challenges to international students especially in academic writing. Therefore, support classes such as EAP have developed in response to this increasingly diverse student population in tertiary education (FLOWERDEW AND PEACOCK, 2001) serving as "specialized English-language teaching grounded in social, cognitive and linguistic demands of academic target situations" (HYLAND, 2006, p.2). Traditionally, EAP focused on the linguistic needs of international students, however this has also been commonly criticized for taking a deficit, surface level view of students' abilities (HYLAND, 2018). EAP now increasingly provides support for a widely diverse group of learners reflecting the thought that academic language does not have 'native speakers' ('NS'), regardless of someone's L1 (FLOWERDEW AND PEACOCK, 2001; LILLIS AND TUCK, 2016). In addition, these classes now commonly focus on a multitude of competencies and knowledge as EAP pedagogical practices have evolved to reflect the complexity of navigating the increasingly heterogeneous academy (HYLAND, 2018).

Originating from the UK and South Africa, the Academic Literacies model evolved from a study skills and socialization model (LEA, 2004; BENESCH, 2001; LILLIS AND TUCK, 2016). The study skills model takes a deficit linguistic perspective by focusing on surface features - such as notetaking, skimming and scanning, time management, grammar, and spelling - which are taught as practical, transferable and functional features of succeeding in academia (LILLIS AND SCOTT, 2007). This approach is criticized for its mechanical, superficial surface level focus and for shifting away from a language focus (LILLIS AND SCOTT, 2007). Therefore, another approach to teaching EAP developed called academic socialization, which focuses on inducting a student to the 'culture' of the academy by learning the norms of the institution (LEA AND STREET, 1998). This socialization, 
however, is often criticized for being implicit where academic writing is seen as transparent, disciplines as stable, and norms reproducible after learning (LEA AND STREET, 2006; LILLIS AND TUCK, 2016). Neither a skills model approach, nor the academic socialization approach, sufficiently recognize institutional - specific practices, changing disciplinary differences, and power within the heterogeneous academy, which prompted the development of Academic Literacies (LILLIS AND TUCK, 2016).

The concept of Academic Literacies, then, encompasses the study skills and academic socialization approaches, acknowledging the pluralization of literacies which vary based on the context in which they occur (LEA, 2004). Literacies are therefore seen as diverse, socially and culturally situated, shifting, contextualized, ideologically shaped and contested (LILIS AND TUCK, 2016). This views literacy events and practices as something that all students, regardless of linguistic background, must learn to navigate (STREET, 2015; WINGATE, 2018). Further, concepts like power, identity, and culture are centrally situated in this navigation (LEA, 2004). Additionally, Academic Literacies recognizes the implicit nature of expectations in academia along with the fact that difficulties detected in writing are often wrongly attributed to language problems (WINGATE, 2018).

Importantly, while stemming from New Literacy Studies and US-based Composition Studies, Academic Literacies did not originally focus on international students but rather on non-traditional home students (LILLIS AND TUCK, 2016). It has now been widely applied to the field of EAP, where Lillis and Tuck (2016) identify both convergences and divergences (table 1) with EAP. It should be noted, though, that Lillis and Tuck (2016) admit that some aspects of the divergences identified are challenged within critical EAP (BENESCH, 2001; TURNER 2004, 2012). Hyland (2018) further artfully explores the criticisms of EAP and shows how EAP has developed to converge more and more with those who criticize aspects of it (e.g. Academic Literacies, English as a Lingua Franca and Critical EAP). Yet Hyland (2018) also admits many of the criticisms are valid - such as that of privileging text and problematization of pedagogy - and raise essential questions which must be addressed. 
Table 1 Divergences of mainstream EAP and Academic Literacies (LILLIS AND TUCK, 2016, PP. 36-37)

\begin{tabular}{|l|l|}
\hline EAP & Academic Literacies \\
\hline Text-focused & Focus on the meaning-maker \\
\hline $\begin{array}{l}\text { Focused on English including 'standard' and } \\
\text { native speaker' focus }\end{array}$ & Nature and status of English challenged \\
\hline Novice-expert trajectory & $\begin{array}{l}\text { Diversity of knowledge and experiences } \\
\text { emphasized }\end{array}$ \\
\hline $\begin{array}{l}\text { Target norms are identifiable, and students } \\
\text { should be inducted into such norms or } \\
\text { encouraged to navigate expectations of } \\
\text { audiences. }\end{array}$ & $\begin{array}{l}\text { Shift and change inherent in academic } \\
\text { discourse, and responsibility of responsiveness } \\
\text { to this is on students, academic communities } \\
\text { and gatekeepers. }\end{array}$ \\
\hline
\end{tabular}

Therefore, the convergences of critical EAP and Academic Literacies are important to identify as they both (LILLIS AND TUCK, 2016):

- Pose questions around external expectations such as who created these expectations and why, should they be adhered to, should they be changed, what might happen if we try to change them, and what are the consequences (good or bad) of upholding them (BENESCH, 2001). Further, the focus is on not just presenting such questions, but on negotiating the answers to them.

- Challenge the monolinguist mindset through recognizing Global Englishes, vernacular, code-meshing, indigenous academic languages and a range of modalities (CANAGARAJAH, 2015B; GALLOWAY AND ROSE, 2014; GARCÍA, 2009; KRESS, 2010; THESEN AND VAN PLETZEN, 2006).

- Question novice-expert trajectories (CANAGARAJAH, 2002; FLOWERDEW AND LI, 2009).

- Call for more holistic methodologies.

- View writing as a social practice which engages multiple participants in the process such as literacy brokers, tutors, assessors and students (HARWOOD ET AL., 2012; LEA AND JONES, 2010).

- Emphasize transformative pedagogies through focusing on negotiation and dialogue, expanding the definition of 'appropriate' resources in the academy to include multimodality, translingualism/translanguaging, and vernacular, and problematizing 'English' and 'Academic' as conceptual categories to recognize increased academic mobility and diversity (ARCHER, 2006; CANAGARAJAH, 20013A, 2015B; LILLIS AND SCOTT, 2007).

- Question what 'risk' means in the academy. 
- See literacy at ideological rather than autonomous (CANAGARAJAH, 2015B, STREET, 2015).

The authors, therefore, do not see critical EAP - especially the theory of translanguaging - and Academic Literacies as incompatible and recognize that elements of both may be identified within this study. Further, as Lillis and Tuck (2016, p.39) state:

There is a danger that researchers/pedagogues stay separate...it will be important that researchers with shared interests and ideological concerns engage with each other's work, both in order to avoid working within conceptual boundaries they seek to disrupt, and as a means to develop richer understandings of knowledge-making in the contemporary world.

Similar calls for engaging with work across disciplines to enrich research has been made by Canagarajah (2015B). Recognizing this, the authors identify similarities between critical EAP and Academic Literacies and use aspects of both throughout this study.

However, an Academic Literacies approach is still 'named' as the primary framework, especially when speaking of implications and recommendations. Not only does Ireland tend to follow the UK in approaches to EAP practices and research, but also many EAP programs, practitioners and training have been transplanted from the UK to Ireland - the name of Academic Literacies is of some familiarity to institutions and practitioners which is of importance to influencing these entities (LILLIS AND SCOTT, 2007). Further, Ireland mirrors the UK's past with an underdeveloped or absent focus on writing or academic language, rather than the well-established status in the US - e.g. long-standing composition courses, writing centers, etc. (LILLIS AND SCOTT, 2007).

In 2010, 19 out of 27 Higher Education Authority institutions in Ireland offered language support, with only 10 of those institutions with support open to all EAL students - not just Erasmus (NÍ CHONAILL, 2014). Many institutions denied a need or responsibility to offer support, and only 4 of the 7 Universities offered any sort of support (NÍ CHONAILL, 2014). In 2018, this number has increased to appear that out of the 35 responding institutions, 26 offer support either centrally or at a faculty level - only 5 universities, 14 institutes of technologies and 7 private institutions (see Figure 12 in CLARKE ET AL., 2018, P.65). However, this may be a generous estimate as the numbers could represent overlapping institutions that provide both faculty and centrally based support (CLARKE ET AL., 2018, P.65). Further, the development or quality of the programs were not assessed (CLARKE ET AL., 2018, P.65). The field of EAP, both in practice and research, can be said to be in the 'umbilical' stages in Ireland. 
Additionally, Ireland is in the midst of widening access to higher education both in terms of 'home' and international students, which introduces a wide range of linguistic backgrounds such as Irish as an L1, immigrants in the Irish primary and secondary school system, vernacular or unique Englishes such as Irish English, other English L1 students, and English as an additional language (EAL) international students (CLARKE ET AL., 2018; SMYTH, 2018). Much of this takes place through access programs and a government internationalization strategy (BRUTON, 2016), mirroring the UK's widening of access discussed in Lillis and Scott (2007).

Academic Literacies, then, allows for the introduction of the idea that programs should be developed to support students in their negotiation of academic discourses and practices regardless of students' $\mathrm{L} 1$ - in a context where institutions need to be convinced of developing such programs in the first place. The researchers propose first advocating for the approach of Academic Literacies on the island, as familiarity with this approach stems from historical and current contact with the UK. Academic Literacies may offer more readily accepted institution-specific, transformative pedagogical implications for the current context of Ireland. The researchers do acknowledge that this study focuses on international students, however they feel that there is a risk of institutions confining EAP support to international students based on research advocating only L2 writing support (despite current research in this field increasingly including English L1 students).

Therefore, with this in mind and research on EAP in tertiary institutions lacking in Ireland, an exploration and description of the context as it relates to academic discourses is needed to aid future research and pedagogical applications of EAP within Ireland. Consequently, this study aims to explore student relationships with and perceptions of the navigation of power, identity, and culture in academic writing within a specific, English - language Irish tertiary context. First, the concepts of power, identity and culture will be explored with the methodology of the study following. Results from the questionnaires and interviews are presented next, and the discussion and implications are presented in the conclusion.

\section{THEORETICAL FRAMEWORK}

\subsection{Power}

Power is an important factor in language and discourse as well as language learning. Power can be seen in or behind discourse, and this research specifically focuses on the latter. 'Power behind discourse' is concerned with the ways in which norms of discourse are shaped (FAIRCLOUGH, 2001A), with authority and 
hierarchy identified as two important influencers within this discussion. According to Fairclough (2001A), those who have power are generally the ones to establish and uphold linguistic norms and conventions. Through time, a naturalization process takes place, in which these conventions and norms become 'common sense' (FAIRCLOUGH, 2001A). As a result, these norms and conventions are commonly thought to have lost their ideological component and come to be seen monolithically, as a set of skills that simply need to be learned and reproduced (FAIRCLOUGH, 2001A).

Recently, however, Academic Literacies scholars have critiqued this practice and, reflecting on normative influences, have identified the EAP classroom as a site of struggle and negotiation (LILLIS, 2001). They argue for the need to take a plurilithic point of view that allows the negotiation of norms, expectations, and meaning-making within the student body to bring about change within normative academic discourse (LILLIS, 2001). They also see a site of struggle in the EAP classroom between the gatekeepers, namely instructors, and EAL students, the latter of whom do not commonly have ownership over the language, and thus power over their writing process (LEA, 2008; LILLIS AND SCOTT, 2007).

The issue of gatekeeping, the act of deciding what is and is not allowed, with regards to language standards is debated not just in terms of EAP and academic writing norms, but within language and English in general (FAIRCLOUGH, 2001A). Varieties of English, which have emerged in many different parts of the world, and the global use of English as a lingua franca are both explored within Global Englishes (GALLOWAY AND ROSE, 2014). The pluralization of English recognized in Global Englishes challenges the conception of the 'NS' 'owning' the language and brings the question of to what extent EAL English speakers are empowered and can claim ownership (JENKINS, 2006; NORTON, 1997). However, there is still plenty of resistance to the concept of Global Englishes. Despite calls for the acknowledgement of Global Englishes, teachers and Englishmedium institutions continue to prioritize standard inner-circle Englishes as the most desirable - and indeed as the only acceptable - convention. The issue of challenging the standards and traditional gatekeepers of the language needs to be particularly considered in the EAP context, since it traditionally operates and exercises power based on 'standard' conventions of academic writing and discourse (CANAGARAJAH, 2001; CHUN, 2015; LILLIS, 2001).

\subsection{Identity}

Identities are seen as socially constructed, negotiated, multiple, multimodal and constantly changing (FLOWERDEW AND WANG, 2015; PEIRCE，1995; 
GEE, 1996; BAKHTIN, 1981; GOFFMAN, 1981). Identities are layered and complex where aspects of identification with languages result in hybridity through contact and mixing (CANAGARAJAH, 2015B). This is in line with Levitt (2001A, B) and Levitt and Glick Schiller (2004)'s view of transnationalism where ways of being represent the social practices and relations an individual engages in, and ways of belonging as the practices that show identities with a particular group. Individuals may be a part of a social space, however they may choose whether or not to identify with any category open to them within that field (LEVITT, 2001A, B; LEVITT AND GLICK SCHILLER, 2004).

The dialogic and negotiable nature of identity construction, however, is not always within access of those who have a lower status or restricted linguistic resources, which limits the performance of certain identities (CREESE ET AL., 2006; CREESE AND BLACKLEDGE, 2015; PAVLENKO \& BLACKLEDGE, 2004). This leaves groups (or individuals) who are able to negotiate their position - and, therefore, may not consider language as central to this negotiation or position - those who aren't, and a third group who negotiate new positions through incorporating a range of linguistic resources (CREESE AND BLACKLEDGE, 2015; GAL, 2006).

In writing, author identity is constructed through interaction with and response to the texts that an individual reads and writes (CHERRY, 1988; GOTTI, 2009; IVANIČ, 1998). This results in an amalgamation of textual and extra-textual resources (MATSUDA, 2001). Prior (2001), then, adds to the description of voice as dialogic between personal, writers expressing stance towards a subject through taking on roles, and social, writers appropriating voices of others through intertextuality to take on social identities (BAKHTIN, 1981; PENNYCOOK, 2001). Further, effect is explored by Matsuda and Tardy (2007) and Matsuda (2001) to highlight how readers construct the writer's voice and therefore shift the concept of voice away from solely relying on the writer to additionally include the interaction of readers and writers in jointly constructing voice. Canagarajah (2015B), then, develops a heuristic analysis for voice featuring identity (including features of a students' history), role (including subject positions students occupy and the expectations that come with such a role), subjectivity (ideological discourses which shape voice - e.g. conventions and norms) and awareness (reflective process) to show how students amalgamate voice and identities outside of the text.

Students often shape their writing to satisfy those who they are attempting to respond to and draw from (i.e. those in power), which shows addressivity and 'inventing' the university (BAKHTIN, 1986; BARTHOLOMAE, 1986). 
Addressivity refers to how students draw from others through their wording and text in their meaning-making to address those they are writing for (BAKHTIN, 1986). 'Inventing the University' refers to voices or to the body of power that students imagine will read and critique their work, and for whom they constantly adapt their voices when responding through academic writing (LILLIS, 2001). In other words, when inventing the university, students imagine the expectations they must meet according to those who they are writing for. Addressivity, on the other hand, is how the student draws upon the cultures and ideologies they have been exposed to in order to meet those expectations. Often, this manifests in tensions between taking on institutional and disciplinary norms on one hand, and the writer's desire for uniqueness and agency on the other hand (LILLIS, 2001; FLOWERDEW, 2011; HYLAND, 2012). Additionally, the concepts of gatekeeping and power discussed above may influence the expression and acceptance of identities and result in possible marginalization and stigmatization (CREESE AND BLACKLEDGE, 2015; FLOWERDEW AND WANG, 2015).

\subsection{Culture}

Culture is now commonly considered as dynamic, contested, saturated with aspects of power, and constantly co- and re-constructed in social spaces (ARCHER, 2008; LEE AND CANAGARAJAH, 2018). However, the concept of culture, especially that of culture in writing, has long been debated, as explored by Casanave (2017). Contrastive Rhetoric, first proposed by Kaplan (1966), attributed aspects of organizational patterns and logic in writing to a learner's culture, which was then said to transfer from their L1 to their L2 writing. Defenders of Contrastive Rhetoric claimed that it was based on the 'Sapir-Whorf Hypothesis' (CONNOR, 1996; KOWAL, 1998), where the more-accepted version of the hypothesis states that language does influence thought (HUNT AND ANGOLI, 1991). However, the discussions on this tend to avoid ideological questions identified in Casanave (2017) with criticism of Contrastive Rhetoric ranging from needing to analyze articles in the students' L1 to the representativeness of the texts of academic discourse (e.g. HINDS, 1983, 1990; KUBOTA, 1997; MATSUDA, 2003; see CASANAVE, 2017 for full discussion). In addition, Contrastive Rhetoric sees cultures as attributed to nations and languages, assuming homogeneity - reminiscent of multiculturalism as defined in Lee and Canagarajah (2018) (ATKINSON, 2004; ATKISON AND MATSUDA, 2013; MATSUDA AND ATKINSON, 2008). This additionally takes a deficit view of students by attributing 'errors' to cultural differences (ZAMEL, 1997). 
This then led to the introduction of Intercultural Rhetoric which considers languages, text type, genres, identity, social contexts, etc. (CONNOR, 2011; LI, 2008). This has influenced fields such as English for Specific Purposes (ESP) and New Literacy Studies, where identifying differences in genres and recognizing cultural and social factors as influences on text has become popular (CASANAVE, 2017). However, this is still criticized for a static and essentialist view of culture along with not recognizing the influence of power (CANAGARAJAH, 2013B; KUBOTA AND LEHNER, 2004, 2005; ATKINSON, 2004). Interculturalism still implies distinct separation between cultures, where it is thought of as a product, not a process, and a noun, not a verb (HEATH AND STREET, 2008; STREET, 1993). These debates surrounding (Inter)Cultural Rhetoric and its acceptance are still unresolved (CASANAVE, 2017). However, with interculturalism criticized for viewing culture in an essentialist way, a move to see culture as practices or activities has been seen (CANAGARAJAH, 2015B; JENKINS, 2014; GARCÍA AND WEI, 2014). Importantly, as Brian V. Street can be said to be a 'father' of Academic Literacies, it follows that this study will take culture to be a verb, moving to transculturalism (LEE AND CANAGARAJAH, 2018; RISAGER, 2006; PENNYCOOK, 2007) rather than staying within the paradigm of interculturalism and Intercultural Rhetoric.

Therefore, transculturalism comes from the concept of contact zones (PRATT, 1992) and a persons' agency in engaging with and/or resisting linguistic and cultural adaptation (ZAMEL, 1997). Zamel (1997) highlights that cultures and languages are dynamic and constantly changing. Lee and Canagarajah (2018) further states that "transculturalism involves situating oneself in liminal social spaces and drawing from values and practices of diverse cultures to constantly reconstruct one's identity and social belonging" (p.3). The focus on transculturalism, then, is not on the product but rather on processes and practices (LEE AND CANAGARAJAH, 2018).

It follows that an examination of perceptions of culture and its negotiation and construction in academic social spaces is important in the present context, as this still may influence a student's concept of academic writing, genres, and conventions. Their perceptions of and participation in such social spaces have the potential to marginalize them as they bring their own culture, habitus, and identity to a new community, the tertiary institution, which has its own specific culture, habitus, and practices that the student must adapt to - potentially resulting in a one-sided re-negotiation of these factors within these spaces (LILLIS, 2001). Together with an examination of the concepts of power and identity, an examination 
of culture taking a transcultural view facilitates an expanded understanding of the apex that influences EAL student academic outcomes in writing.

\section{METHODOLOGY}

This research was conducted using two data collection instruments: questionnaires and interviews. The questionnaire was informed by Pedersen (2010), Usyal (2008) and theoretical underpinnings found in the literature review concerning the main parameters of power, identity, and culture. These parameters were not defined in the questionnaire so as not to restrict the participants' understanding of these terms. Interviews took a semi-structured format and were transcribed using markup informed by Du Bois (2000, 2003), Breiteneder, Pitzl, Majewski, and Klimpfinger (2006), and Atkinson and Heritage (1984).

Following ethical approval, purposive sampling was used for the questionnaire with the criteria being set as EAL students completing their academic studies at a specific English-medium tertiary institution in Ireland (COHEN ET AL., 2011). In 2016, the year in which data collection was completed, this Irish university offered non-credit bearing EAP support classes to students as an optional two-hour a week evening course during the 12 -week term. With approximately 100 students electing to participate, 10 classes were offered where the tutors had complete autonomy over curricula and assessment for their individual classes. In addition to in-term optional classes, the institution offered an eight-week, 20 hour a week, summer course for conditionally and unconditionally accepted students. During this time, these summer courses also did not have a centralized or standardized curriculum or assessment. Conditionally accepted students were required to re-take IELTS at the end of the course. These seemingly underdeveloped courses are in line with the development of the EAP sector in Ireland, which has only recently began to receive attention.

Participants were asked to complete the questionnaire in an online format distributed via social media, garnering a total of 108 responses. Participants could also express interest in a follow-up interview. Three case studies were then chosen from this sample to reflect a diversity of disciplines and social strata (Table 1). Importantly, the sample population was taken from all EAL students at the institution, and therefore none of the case study participants had opted to take the EAP support classes offered through the University. Additionally, only six of the 108 questionnaire responses indicated participation in the EAP courses offered by the institution. 
Table 2. Case study participant demographics

\begin{tabular}{|l|l|l|l|l|l|}
\hline $\begin{array}{c}\text { Case } \\
\text { Study }\end{array}$ & \multicolumn{1}{|c|}{ Discipline } & Nationality & $\begin{array}{c}\text { Gen- } \\
\text { der }\end{array}$ & \multicolumn{1}{|c|}{ Age } & \multicolumn{1}{|c|}{ Degree Level } \\
\hline$\# 1$ & English Literature & Austrian & F & 21 & Visiting Undergraduate \\
\hline$\# 2$ & Global Health & Turkish & $\mathrm{M}$ & 35 & Full-time Postgraduate (masters) \\
\hline$\# 3$ & Physics & Italian & $\mathrm{M}$ & 25 & Full-time Postgraduate $(\mathrm{PhD})$ \\
\hline
\end{tabular}

Questionnaires were analyzed quantitatively using SPSS to provide descriptive statistics. Interviews and questionnaire open questions were coded using emerging themes. The process of analysis and emerging themes were viewed through the lenses of critical discourse analysis (cda). While the analysis was influenced by the analytical framework identified by Fairclough (2001B), it is classified as thematic discourse analysis through a critical lens (ROGER, 2011). This type of discourse analysis is commonly called cda (lowercase) rather than CDA (i.e. Fairclough's critical discourse analysis). These codes were confirmed by a supervisor to increase reliability. All participants were EAL students studying at an Irish institution where all courses and administration are conducted in English.

\section{RESULTS}

\subsection{Questionnaires}

Out of the 108 total participants, thirty-two indicated English as their first academic language (FAL), seventy-three named their first language (FL) as their FAL, and 3 identified yet another different language as their FAL.

Overall, while participants feel confident, comfortable, and able to express themselves in English when writing academically, for a majority there is greater confidence in their FAL and preference for the use of their FL when writing academically (Figure 1). In addition, the questionnaire indicated that participants feel they are able to express themselves fully when writing academically in English. However, many participants prefer the use of their FL over English as their academic language of choice, thus confirming the limitation placed on them by the Englishmedium university. 


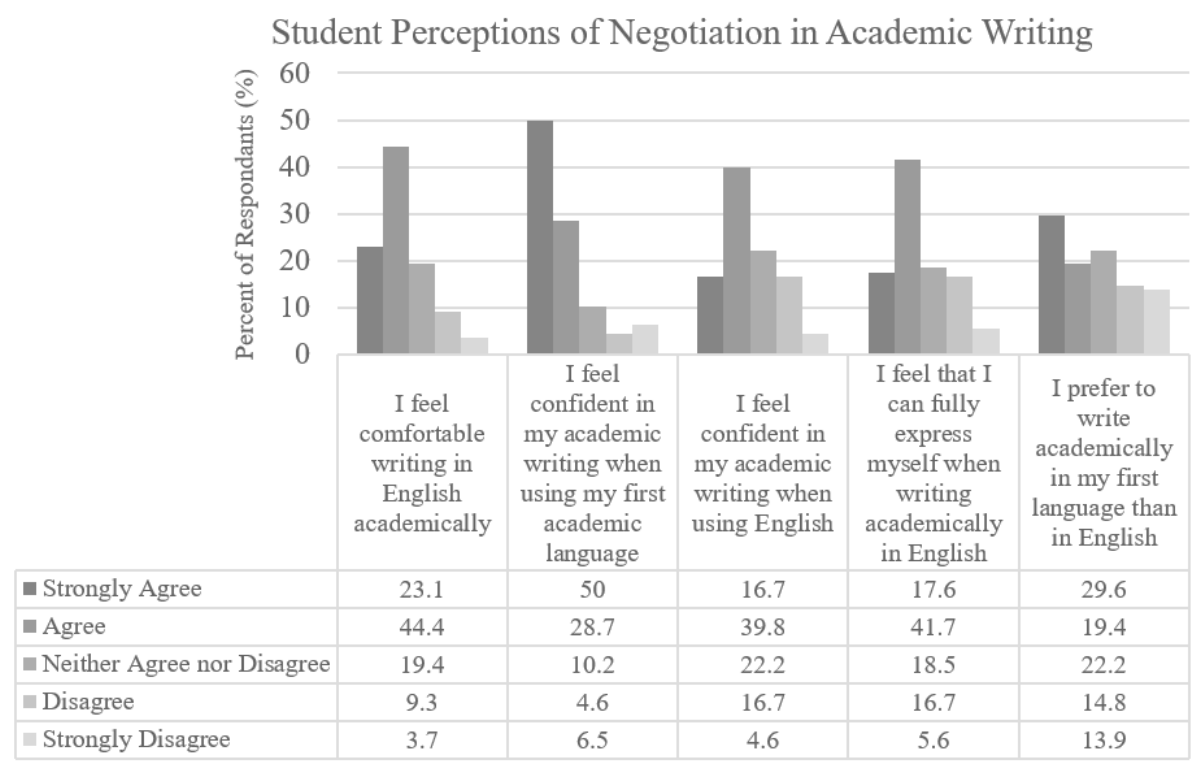

Figure 1. Student perceptions of negotiation in academic writing

Another aspect explored is that of privileged and dominant discourse in the context of Global Englishes (Figure 2).

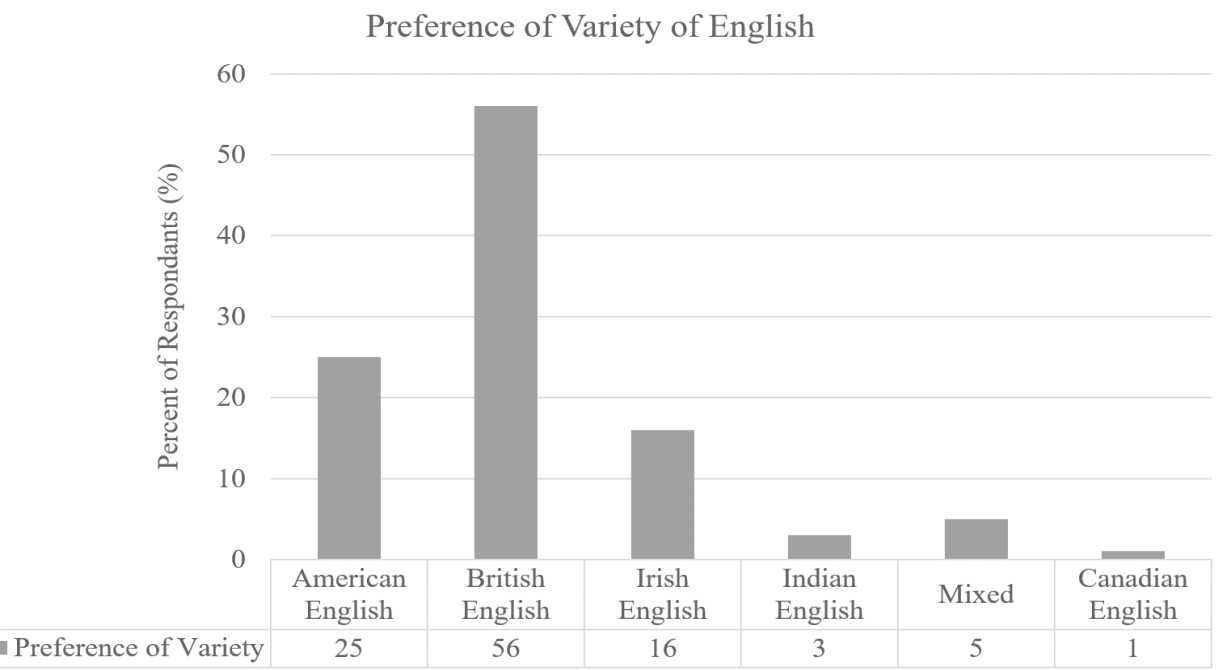

Figure 2. Preference of variety of English 
Clearly, British English is the preferred variety, with 56\% of participants indicating this preference. The reasons for this were complex and included multiple categories as seen in table 3 .

Table 3. Participant - identified reasons for preference of English variety chosen

\begin{tabular}{|l|l|}
\hline Category & Number of People \\
\hline Education & 34 \\
\hline Familiarity & 33 \\
\hline Way of Speaking & 37 \\
\hline Prestige & 9 \\
\hline Culture & 8 \\
\hline Confidence & 4 \\
\hline
\end{tabular}

It can be seen that there are three main factors influencing preference for a specific variety: (1) way of speaking, (2) familiarity, and (3) education. The way of speaking associated with the variety of English includes the accent, comprehensibility of users, and style. Familiarity includes exposure from the participant's country of origin or residence, media, and work. The educational aspect is seen through requirements from higher education (e.g. requirement for writing using a certain variety), and the variety taught during their English learning history. Importantly, factors such as grammar and spelling, rather than just accent, were identified as influencing the participant's choice. Other reasons included prestige (elegance, colonialism, and correctness), culture (identification with or preference for a certain culture), and confidence in their own ability to speak and write that variety.

When it comes to identity, English seems to play a significantly larger role in their academic identity versus their identity as a whole. Out of 108 participants, 74.1\% identified their FL as representing their identity as a whole and only $9.3 \%$ indicated the same for English (Figure 3). 
Language that Represents Identity as a Whole

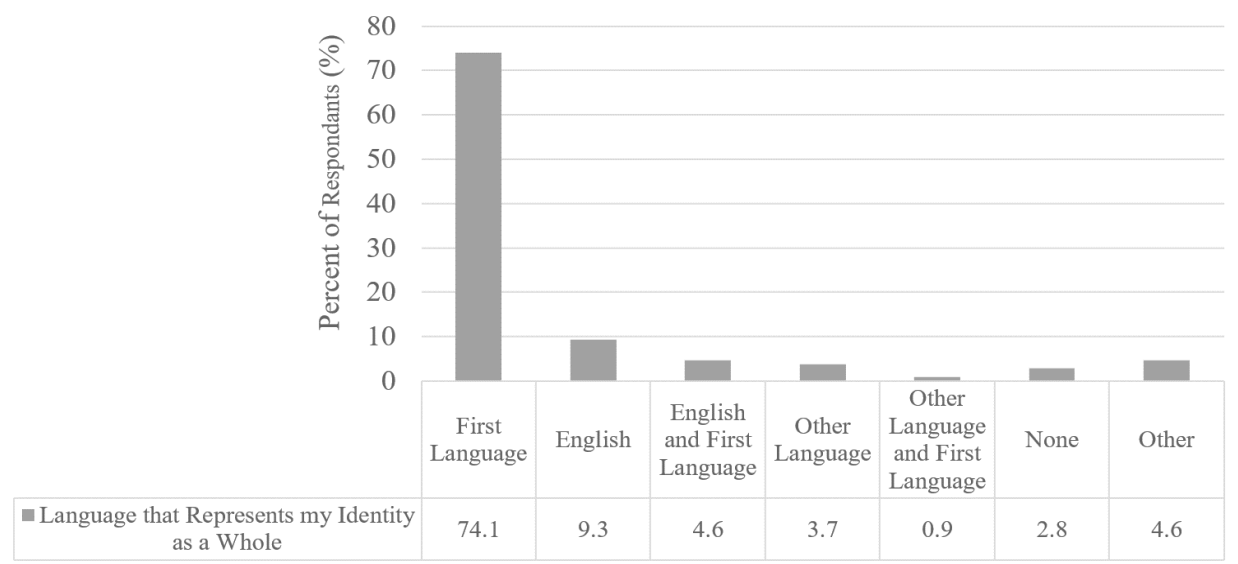

Figure 3. Language that represents identity as a whole

On the other hand, $56.4 \%$ stated that English fits their identity in academic writing in some capacity while $12.1 \%$ stated that it was not a fit (Figure 4 ). When asked to explain their reasoning for judging the transferability of English to their identity in academic writing (Question 32), four themes emerged from participants' answers: 'language', 'meaning-making and expression', 'regulation, rules, and authority', and 'educational experience' (Table 4). Again, these answers were complex and often included more than one category. Of the 42 participants that answered this question, most answers fell into the 'meaning-making and expression' category. All participants gave varied answers with conflicting answers towards English representing their identity in academic writing. 
How Well English Fits Identity in Academic Writing

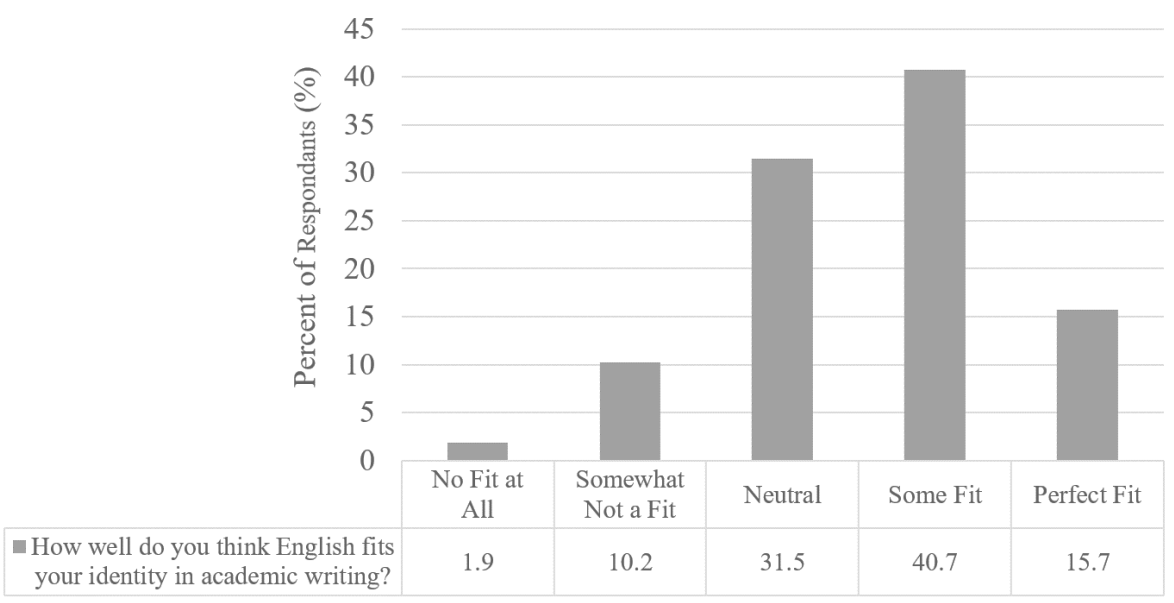

Figure 4. How well English fits identity in academic writing

Table 4. Discourse analysis for reason for level of fit of English to identity in academic writing

\begin{tabular}{|l|l|}
\hline Category & Number of People \\
\hline Language & 11 \\
\hline Meaning-making and expression & 16 \\
\hline Regulation, rules, and authority & 9 \\
\hline Educational experience & 12 \\
\hline
\end{tabular}

Participants had conflicting views towards English as representing their identity in their academic writing, stating some negative and positive outlooks. Overall, these four categories showed that English is seen as structured, clear, and as a main choice of expressing identity through academic writing, largely due to experience. However, participants stated that the rules and perceived neutrality of academic writing restrict their expression of identity. Other aspects showed conflict and struggle between English and their other languages in terms of meaning-making and expression in academic writing.

Participants' views are generally positive towards the expression of identity in academic writing (Figure 5). They indicated that personality, style, and identity should be shown in academic writing with a more positive slant towards the belief that this expression will not make the argument weaker. Concerning the ease of expressing personality, style, or identity, participants felt that it is easier in their FAL rather than English. We are then seeing the sense that English academic 
writing encapsulates a neutralized mode of communication while the FAL invariably channels more of the author's identity.

\begin{tabular}{|l|l|l|l|l|}
\multicolumn{1}{c|}{ Student Perceptions of Identity Negotiation in Academic } \\
\hline
\end{tabular}

Figure 5. Student perceptions of identity negotiation in academic writing

Participants felt positively towards the expression of culture in academic writing, both in general and within their own academic writing, regardless of language (Figure 6). In terms of expressing their culture through academic writing, participants felt positively that they can express this through both English and slightly more through their FAL. Additionally, participants felt that culture and identity can be present without making the argument weaker in academic writing. 


\section{Student Perceptions of Cultural Negotiation in Academic Writing}

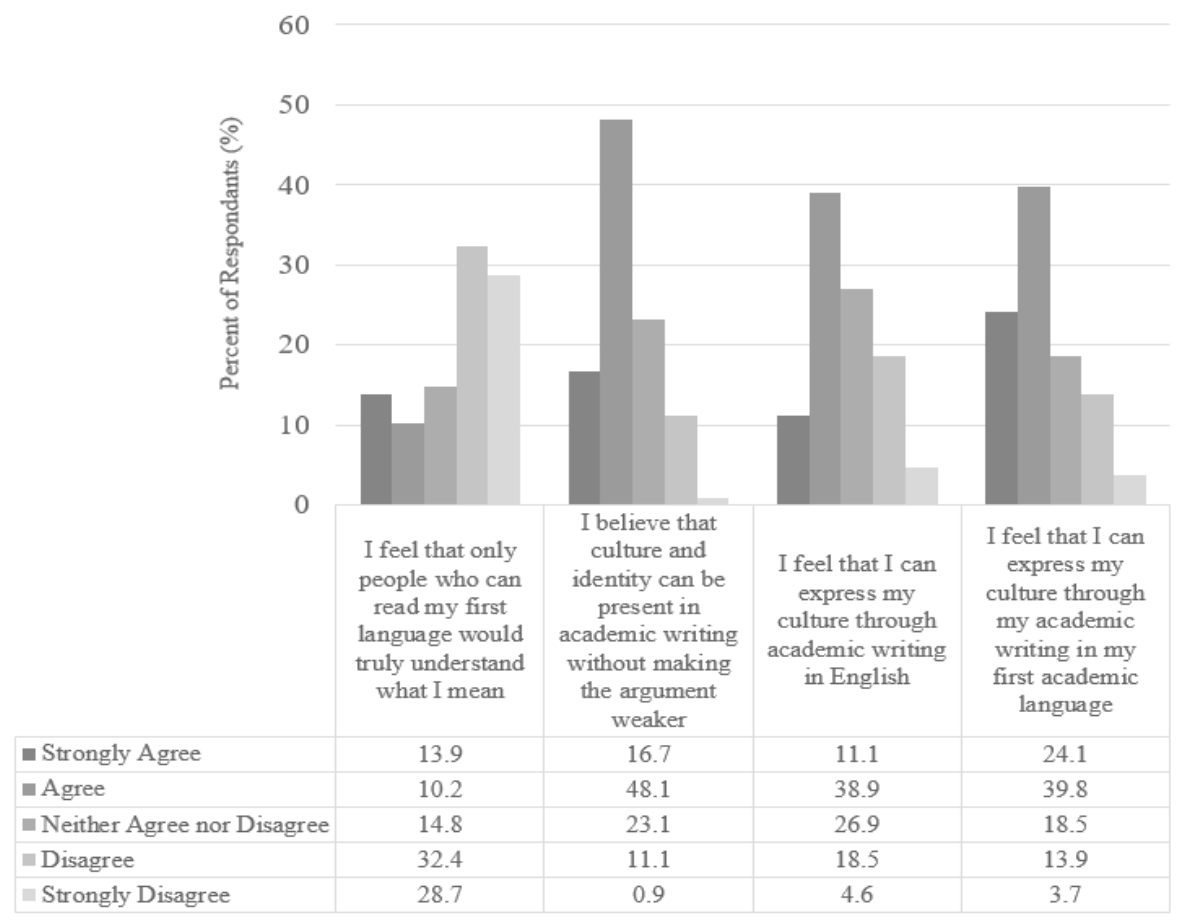

Figure 6. Student perceptions of cultural negotiation in academic writing

\subsection{Case studies}

Case studies focused on interviews with individual students (S\#1, S\#2, S\#3) from different fields of study where the researcher identified categories emerging from the interviews (Table 5). Every instance, defined as an utterance or turn, of the category was counted and further analyzed. Almost all utterances fit into more than one category.

Table 5. Discourse analysis categories for interviews

\begin{tabular}{|l|l|}
\hline \multicolumn{1}{|c|}{ Categories } & \multicolumn{1}{c|}{ Definition } \\
\hline Regulation, rules, and authority & Enforcement and imposition of norms and rules \\
\hline Struggle and resistance & Contradicting opinions and ideas or going against norms \\
\hline Inventing the University & $\begin{array}{l}\text { Creation of the audience of or expectations imposed on } \\
\text { the writing (BARTHOLOMAE, 1986) }\end{array}$ \\
\hline
\end{tabular}




\begin{tabular}{|l|l|}
\hline Habitus & $\begin{array}{l}\text { Reactions to situations and a 'feel for the game' } \\
\text { (BOURDIEU, 1992) }\end{array}$ \\
\hline Culture & Aspects of national, ethnic, and local culture \\
\hline Voice and identity & $\begin{array}{l}\text { Dialogic expression of the self and culture in writing } \\
\text { (LILLIS, 1997) }\end{array}$ \\
\hline Meaning-making & $\begin{array}{l}\text { How texts, words, and intended meaning are } \\
\text { understood and conveyed (BAKHTIN, 1986) }\end{array}$ \\
\hline Ownership and empowerment & $\begin{array}{l}\text { Gaining or having a feeling of authority and a right to } \\
\text { own or use language independent of 'native speakers' } \\
\text { (GALLOWAY AND ROSE, 2014) }\end{array}$ \\
\hline $\begin{array}{l}\text { Communities of discourse and } \\
\text { dominant discourse }\end{array}$ & $\begin{array}{l}\text { Privileged and predominant language, uses of language, } \\
\text { and social groups where this language is privileged } \\
\text { (FAIRCLOUGH, 2001A) }\end{array}$ \\
\hline Learned process & $\begin{array}{l}\text { Aspects of academic writing that improve with } \\
\text { familiarity or experience }\end{array}$ \\
\hline
\end{tabular}

Table 6 shows the instances of occurrence of the specific categories in the interviews. It is important to note that each utterance within an interview often featured overlapping categories and could be marked for more than one category in the analysis.

Table 6. Discourse analysis of the interviews categorized by instances

\begin{tabular}{|l|l|l|l|}
\hline Category & $\begin{array}{l}\text { Number of } \\
\text { Instances in } \\
\text { Case Study 1 }\end{array}$ & $\begin{array}{l}\text { Number of } \\
\text { Instances in } \\
\text { Case Study 2 }\end{array}$ & $\begin{array}{l}\text { Number of } \\
\text { Instances in } \\
\text { Case Study 3 }\end{array}$ \\
\hline Regulation, rules, and authority & 16 & 14 & 21 \\
\hline Struggle and resistance & 14 & 16 & 17 \\
\hline Inventing the University & 5 & 1 & 2 \\
\hline Habitus & 2 & 2 & 1 \\
\hline Culture & 3 & 4 & 4 \\
\hline Voice and identity & 10 & 6 & 12 \\
\hline Meaning-making & 1 & 4 & 10 \\
\hline Ownership and empowerment & 2 & 6 & 5 \\
\hline $\begin{array}{l}\text { Communities of discourse and dominant } \\
\text { discourse }\end{array}$ & 4 & 9 & 10 \\
\hline Learned process & 4 & 9 & 8 \\
\hline
\end{tabular}

Within the high number of 'regulation, rules, and authority' category, all participants expressed that they find academic writing to be filled with strict and arbitrary rules. 
Similarly, S\#3 identified academic writing as 'technical' where you are 'forced' or 'bonded' to using certain vocabulary and structures, which may restrict freedom. Further, S\# 1 viewed academic writing as stifling and formulaic. She found academic writing to be frustrating with a high focus on referencing and citation as well as following arbitrary, learned rules. Within citation and referencing, a struggle was identified in negotiating her understanding of and fairly representing the author's meaning. Additionally, she saw professors and their expectations as restricting or guiding what is allowed in academic writing. Interestingly, she felt less restricted to these rules and expectations and felt that she could insert herself more into the writing at the institution in Ireland, as it was allowed more than in her home university, thus establishing the existence of heterogeneous university climates.

The culture and identity of the writers were seen to be restricted by these rules, although the visibility of these aspects was felt to be dependent on many factors, such as the reader having familiarity with the culture of the writer, content, and the field of study. The participants stated that they cannot ever truly hide themselves in their writing and that all writing reflects the author, their personality, and past educational history. All stated that to increase objectivity, they identify ways to include themselves in their writing through vocabulary, through sources, or by talking about their home country. S\#3 went on to further explain that he can see his culture through metaphors and structures from his native language, although he doubts the appropriateness of these phrases. He also considered that academic writing is ultimately culturally homogenous due to the mobility of academics, catch phrases that are commonly used, and heavy editing of articles. However, this may in fact reflect the concept of transculturalism, where norms, culture, identity and linguistic resources are co-constructed and negotiated, rather than the stripping of culture that the student described. Interestingly, all participants stated that their identity does not change with their language, but their expression of their identity changes based on the language they choose to write in.

For S\#2, the expression of culture in academic writing brought up the contrast between Turkish and English and the category of 'communities of discourse and dominant discourse'. He felt that English is more valid within the academic setting, showing a conditioning toward English as a dominant discourse. This sentiment is reiterated by S\#3. Further, S\#2 felt that he does not use proper words to express himself. He found himself at first translating English articles to Turkish and then back to English as his writing is mainly influenced by what he has previously read, although with practice he began to conform more to the dominant discourse by thinking directly in English. 
This led to the theme of 'learned process'. As seen, English being the dominant discourse in S\#3's field, he felt that while he still has a lot to learn to become more confident, speaking English helps his vocabulary for academic writing. In a general sense of academic writing, he believes that after reading and writing for an extended period of time, academic writing begins to come naturally. Throughout the interview, S\#2 spoke about how his experience in Turkish academia made expression and writing easier but that this was his first experience within English. He still felt a preference to write academically in Turkish but believed that could change with experience. Additionally, he pointed out that he had to learn how to write academically in Turkish, and that it felt as though he had to re-learn this process in English, indicating barriers to the transferability of academic standards across languages.

Aspects of 'inventing the university' and 'habitus' were evident in each interview. Expectations were described as ambiguous, and often feedback and perceived expectations do not align. While these expectations are felt to depend on professors, institutions, and even assignments, S\#2 and S\#3 expressed that the expectation for successful communication and clarity remains consistent regardless of the context. Further themes of 'regulation, rules, and authority' and 'struggle and resistance' were also shown in this as, according to $S \# 3$, the professors determine what is to be included and are regarded as the 'boss'. Reiterating this, unless certain rules are explicitly expressed or asked, S\# 1 felt that she would not include these in academic writing. Linked with habitus, she expressed doubt about what professors actually want her to do, and therefore she expressed that she lacked a 'feel for the game', although at other points in the interview she expressed that through learning rules there was more of a sense of what is expected.

In terms of 'ownership and empowerment', $\mathrm{S \# 3}$ expressed that English is the only way to be published and recognized within the field. He further expressed that only if you are at a certain level, or well known, can you deviate from the norms of using English as the dominant discourse. Further, the issues of content and 'NS' were brought up repeatedly. $\mathrm{S} \# 2$ felt strongly that content is more important than language when speaking about empowerment and expression. He also spoke about using 'NS' for editing and issues of professors and IELTS scores determining what is thought of your academic writing, which brought up themes of ownership and authority. S\#3 felt that 'NS' know best and doubts his ability in measurement to a 'NS'. However, it could be read that by expressing that English should be used in science, and that even in his hometown they speak in English when speaking 
of science, that he felt a level of ownership over English. These examples show attribution of ownership and authority to 'NS', and the use of 'NS' as a yardstick.

Within all of these themes, there is an element of struggle and resistance, which formed its own theme. S\# 1 had a significant amount of contradicting opinions and frequently asked for validation. Further, the tone of her voice, which was lost in the transcription, showed her struggle between replicating writing norms and placing herself within the texts. Using noticeably faster speech or words such as 'maybe', S\#2 often cut into his own expression by contradicting himself or showing that there was conflict between his personal opinion and norms. Additionally, he often seemed to place the burden of finding the right words on himself and struggled to find the 'correct' expressions to fit within his new community. S\#3 cut into his own answers with contradicting statements. Additionally, he was not always sure of his answers as seen through clarification and expressed doubt. Within previously discussed themes, they expressed difficulty with norms, figuring out what is expected, and negotiating expression. They were still unclear about the rules and expectations within academic writing.

\section{DISCUSSION AND CONCLUSION}

The issue of struggle and resistance highlighted in Academic Literacies (LILLIS, 2001), and translanguaging research where identities and languages are fluid (CANAGARAJAH 2015A, B; LEE AND CANAGARAJAH, 2018), became specifically apparent during the analysis. Within the questionnaire, although participants revealed that they were comfortable and confident writing academically in English, their preference for their FL in academic writing leads to the possibility of struggle and resistance against the dominant norms of higher education, in which English is positioned as the official language of discourse. Additionally, the open answers to English fitting their academic identity showed that, while each language has particular benefits in terms of meaning-making and expression, also discussed by Lillis (2001) and Canagarajah (2015A), often no one language could fully represent a person within their academic writing.

These sentiments were shared in the interviews where participants felt that the expression of their identity changes depending on the language that they use, but their identity itself remains the same at that moment in time. This demonstrates participants negotiating their struggle with conflicting views towards using either language within their academic writing, and the plurality of voice in academic writing. Language, then, is never developed or mastered fully enough to express 
the abstract thoughts and concepts of the student and, as translanguaging studies have shown, there is benefit to using multiple languages in the writing process (CANAGARAJAH, 2006B; MOTLHAKA AND MAKALELA, 2016; GARCÍA, 2017). Moreover, as broader theories of identity illustrate, identity can change over time, especially in situations of language contact and diverse social communities (GUNN, 2006; HALL, 1994; IVANIČ, 1998; MATSUDA, 2015).

Following closely to the use of multiple languages to express identities and varying levels of comfort writing in multiple languages is that experience and familiarity with a language in academic writing accounts for increased comfort and preference for that language. This, along with the identification of culture and identity in vocabulary and structures unique to their self-identified cultures (e.g. case study \#3), can be seen as a reflection of resistance to the norm of the 'NS' and dominant discourse as well as support for shuttling between languages, Global Englishes and a plurilithic view of English (GALLOWAY AND ROSE, 2014; CANAGARAJAH, 2006A). Importantly, this also revealed the interrelation and plurality of identity, culture, and language, as all answers containing identity or culture also contained the other. These themes can be seen in many scholars' calls for intelligibility as the decider of appropriacy and the need for the community to also change in response to new members, rather than the members change to reach an arbitrary 'NS' yardstick (JENKINS, 2014; MAURANEN, 2012; CRYSTAL, 2003).

Further struggle was seen in this question regarding habitus as many participants identified conflicting views on having a 'feel for the game'. Many participants identified that they negotiate and struggle with perceived expectations, also known as 'inventing the university' and habitus (BOURDIEU, 1992; BARTHOLOMAE, 1986), and expressed feelings of validity when feedback is given. These perceived expectations and feedback were not always matched. As seen in other studies, this could lead to marginalization through the gatekeeping aspect that happens within universities (LILLIS, 2003; FLOWERDEW, 2008).

Additional struggle was seen in all three interviews through contradictions, conflict, and uncertainty. This could be from trying to negotiate cultural and power differences in their new community by resisting and conforming to norms (FAIRCLOUGH, 2001A; LILLIS, 2001). There is an aspect of gatekeeping in this as while professors determine the expectations and determine academic success based on academic writing, the participants show that it is still a guessing game and expectations may remain implicit (CANAGARAJAH, 2001). 
The findings suggest that power and rules are upheld not just by the institution, but by the wider social structure (FAIRCLOUGH, 2001A). To illustrate this, all three participants felt that the rules imposed on them in academic writing were arbitrary and restrictive. They felt that rules and expectations may also, and should, restrict these expressions of power, identity, and culture in academic writing on some level. However, the common rule that academic writing should remain objective (HYLAND, 2006), which often means stripping it of identity and culture, was resisted through the views expressed that culture and identity should be shown and, importantly, would not hurt the argument of the academic writing. In fact, the participants would like to see more self-expression and stated that it may not be detrimental in academic writing.

This indicates the presence of struggle as described in Academic Literacies, where it is stated that individual institutional power structures influence academic writing and that struggle is inherent in these institutions and academic writing (LEA, 2008; LILLIS, 2003). Further, it leads to the questions of who is making the rules and where the authority to can impose those rules comes from (FAIRCLOUGH, 2001A). This shows what Lillis (2001) identified in her studies of what is allowed to be said and by whom (FAIRCLOUGH, 2001A). This additionally shows how 'the game' is often implicit, changing, and may also be variable depending on instructors, institutions and disciplines (LILLIS ET AL., 2016).

Aspects related to the replication of norms set by the dominant discourse also became apparent in this analysis. Interestingly, the preference for inner circle varieties of English, specifically British English, shows a preference for the dominant discourse of the higher institution - something also found by Canagarajah (2013A). This suggests socialization, communities of discourses, replication of norms, the influences of authority, and 'NS' standards as seen in many Academic Literacies studies (LEA, 2008; LILLIS, 1997, 2003; TURNER, 2012), which are also apparent when looking at the high degree of identification with English in academic writing. This also importantly highlights linguistic markets and linguistic capital where different languages, and indeed standard norms, hold higher 'currency' and may be seen as more desirable for the benefits gained through using such languages (BOURDIEU, 1991). However, while the students may shuttle between linguistic resources to gain access to different social spaces (CANAGARAJAH, 2013A), power is influential on these 'markets' which may restrict the access or acceptance of an individual (CREESE AND BLACKLEDGE, 2015).

Another aspect of authority and ownership is that of the 'NS' standard. All participants felt that 'NS' 'know best' and that their academic writing is not up to 
the level of 'NS'. This reflects the overarching theme of 'NS' standard English being used as a yardstick in English language learning and academia (GALLOWAY AND ROSE, 2014; JENKINS, 2006). On the other hand, however, the identification with English in academic writing, along with the positive feelings of being confident and comfortable writing in English also, challenges the monolithic stance of English where ownership is attributed to 'NS' and shows the plurilithic stance of Academic Literacies in which EAL English speakers can claim ownership of English (LILLIS AND CURRY, 2010; LILLIS AND SCOTT, 2007). There is an expression of transculturalism (LEE AND CANAGARAJAH, 2018) through the feeling of ownership by the participants as they feel empowered by English and stated that English is their preferred academic language as well as the dominant discourse of academia.

This study's overall findings are consistent with research on Academic Literacies that explore pedagogy and struggle within non-traditional and EAL students (CANAGARAJAH, 2006B; KAUFHOLD, 2015; LEA, 1998; LILLIS, 2001, 2006; TURNER, 2012). Furthermore, the results provide implications for EAP pedagogy, by illuminating the necessity of supporting students as they negotiate disciplinary as well as institutional norms, rules, and expression of power, identity, and culture. As suggested by Lillis (2001) a heuristic framework for Academic Literacies can be used in EAP to work through these negotiations with students. Rather than addressing superficial surface skills, a deeper focus on how to navigate individual requirements and expectations within specific environments is needed. Important aspects of this, as addressed by Lillis et al. (2016), include talkback sessions, one-on-one navigation of the writing process, attention to multimodality, and promotion of critical thinking.

As a limitation, questionnaire results were not analyzed for disciplinary differences as this was beyond the scope of the paper; however, this is an important factor for future research to consider. Further, it should be noted that literature identifies such issues of struggle within 'NS' as well, however, this study remained focused on EAL students due to the scope. The researchers encourage more research within Ireland investigating the application of Academic Literacies to all cohorts, along with the subsequent development of academic writing supports for all students. Providing support to students to navigate aspects of identity, culture, and power in their academic writing can increase their chances of academic success. It is suggested that the institution involved in this study further develop resources and programs to realize these important aspects of student support. 


\section{REFERENCES}

ARCHER, A. (2006). A multimodal approach to academic 'literacies': Problematising the visual/verbal divide. Language and Education. v. $20 \mathrm{n}^{\circ}$ 6, pp. 449-462.

ARCHER, A. (2008). Cultural studies meets academic literacies: Exploring students' resources through symbolic objects. Teaching in Higher Education. v. 13 nº 4, PP. 383-394.

ATKINSON, D. (2004). Contrasting rhetorics/contrasting cultures: Why contrastive rhetoric needs a better conceptualization of culture. Journal of English for Academic Purposes. v. $3 \mathrm{n}^{\circ} 4$, pp. 277-289.

ATKINSON, D.; MATSUDA, P. K. (2013). Intercultural rhetoric: A conversation - the sequel. In D. Belcher; G. Nelson (Eds.), Critical and corpus-based approaches to intercultural rhetoric. Ann Arbor: University of Michigan Press, pp. 227-242.

ATKINSON, J. M.; HERITAGE J. (eds.). (1984). Structures of Social Action: Studies in Conversation Analysis. Cambridge: Cambridge University Press.

BAKHTIN, M. (1981). The Dialogic Imagination. Four Essays by M. Bakbtin. Austin: University of Texas Press.

BAKHTIN, M. (1986). Speech genres and other late essays. Austin, TX: University of Texas Press.

BARTHOLOMAE, D. (1986). Inventing the University. Journal of Basic Writing. v. $5 \mathrm{n}^{\circ} 1$, pp. 4-23.

BENESCH, S. (2001). Critical English for Academic Purposes: Theory, Politics and Practice. New Jersey: Lawrence Erlbaum Associates Inc.

BOURDIEU, P. (1991). Language and symbolic power. Cambridge, UK: Polity Press.

BOURDIEU, P. (1992). The Logic of practice. Cambridge: Polity Press.

BREITENDER, A.; PITZL, M.; MAJEWSKI, S.; KLIMPFINGER, T. (2006). Voice Recording: Methodological Challenges in the Compilation of a Corpus of Spoken ELF. Nordic Journal of English Studies. v. 5 n ${ }^{\circ}$ 2, pp. 161-188.

BRUTON, R. (2016). Irish education globally connected: An international education strategy for Ireland, 2016-2020. Available at: > https://www.education.ie/en/Publications/Policy-Reports/ International-Education-Strategy-For-Ireland-2016-2020.pdf $<$ 
CANAGARAJAH, S. (2001). Addressing Issues of Power and Difference in ESL Academic Writing. In: Flowerdew, J.; Peacock, M. (eds.), Research Perspectives on English for Academic Purposes. Cambridge: Cambridge University Press, pp. 117-131.

CANAGARAJAH, S. (2002). Multilingual writers and the academic community: Towards a critical relationship. Journal of English for Academic Purposes. v. $1 \mathrm{n}^{\circ} 1$, pp. 29-44.

CANAGARAJAH, S. (2006a). The place of world Englishes in composition: Pluralization continued. College Composition and Communication. v. 57 n 4 , pp. 586-619.

CANAGARAJAH, S. (2006b). Toward a writing pedagogy of shuttling between languages: Learning from multilingual writers. College English. v. 68 nº 6, pp. 589-604.

CANAGARAJAH, S. (2013a). Critical academic writing and multilingual students. Ann Arbor: University of Michigan Press.

CANAGARAJAH, S. (2013b). From intercultural rhetoric to cosmopolitan practice: Addressing new challenges in lingua franca English. In D. Belcher; G. Nelson (Eds.), Critical and corpus-based approaches to intercultural rbetoric. Ann Arbor: University of Michigan Press, pp. 203-226.

CANAGARAJAH, S. (2015a). "Blessed in my own way": Pedagogical affordances for dialogical voice construction in multilingual student writing. Journal of Second Language Writing. v. 27, pp. 122-139.

CANAGARAJAH, S. (2015b). Clarifying the relationship between translingual practice and 12 writing: Addressing learner identities. Applied Linguistics Review. v. $6 \mathrm{n}^{\circ}$ 4, pp. 415-440.

CASANAVE, C. P. (2017). Controversies in second language writing: Dilemmas and decisions in research and instruction (2 ed.). Ann Arbor: University of Michigan Press.

CHERRY, R. D. (1988). Ethos versus persona self-representation in written discourse. Written communication. v. $5 \mathrm{n}^{\mathrm{o}} 3$, pp. 251-276.

CHUN, C. W. (2015). Power and meaning making in an EAP classroom: Engaging with the everyday. Bristol, Buffalo \& Toronto: Multilingual Matters.

CLARKE, M.; HUI YANG, L.; HARMON, D. (2018). The internationalisation of Irish bigher education. Available at: > http://hea.ie/assets/uploads/2018/07/report internationalisation of education 2018.pdf. $<$ 
COHEN, L.; MANION, L.; MORRISON, K. (2011). Research methods in education. Oxon: Rutledge.

CONNOR, U. (1996). Contrastive rbetoric: Cross-cultural aspects of second language writing. Cambridge, UK: Cambridge University Press.

CONNOR, U. (2011). Intercultural rbetoric in the writing classroom. Ann Arbor: University of Michigan Press.

CREESE, A.; BLACKLEDGE, A. (2015). Translanguaging and identity in educational settings. Annual Review of Applied Linguistics. v. 35, pp. 20-35.

CREESE, A.; BHATT, A.; BHOJANI, N.; MARTIN, P. (2006). Multicultural, heritage and learner identities in complementary schools. Language and Education. v. $20 \mathrm{n}^{\mathrm{o}} 1$, pp. $23-43$.

CRYSTAL, D. (2003). English as a global language. Cambrdige: Cambridge University Press.

DU BOIS, J. W. (ed.). (2000). Santa Barbara corpus of spoke American English, part 1. Philadelphia: Linguistic Data Consortium.

DU BOIS, J. W. (ed.). (2003). Santa Barbara corpus of spoken American English, part 2. Philadelphia: Linguistic Data Consortium.

FAIRCLOUGH, N. (2001a). Language and power. Harlow: Longman.

FAIRCLOUGH, N. (2001b). The Discourse of New Labour: Critical Discourse Analysis. In: WETHERELL, M.; TAYLOR, S.; YATES, S. (eds.), Discourse as Data: A Guide for Analysis. London: Sage Publications, pp. 229-266.

FLOWERDEW, J. (2008). Scholarly writers who use English as an additional language: What can Goffman's "stigma" tell us? Journal of English for Academic Purposes. v. 7 n 2 , pp. 77-86.

FLOWERDEW, J. (2011). Action, content and identity in applied genre analysis for ESP. Language Teaching. v. $44 \mathrm{n}^{\mathrm{O}} 4,516-528$.

FLOWERDEW, J.; LI, Y. (2009). The globalization of scholarship: Studying Chinese scholars writing for international publication. In R. Manchón (Ed.), Writing in foreign language contexts: Learning, teaching, and research: Multilingual Matters, pp.156-182. 
FLOWERDEW, J.; PEACOCK, M. (2001). Issues in EAP: A preliminary perspective. Research Perspectives on English for Academic Purposes. pp. 8-24.

FLOWERDEW, J.; WANG, S. H. (2015). Identity in academic discourse. Annual Review of Applied Linguistics, v. 35, 81-99.

GAL, S. (2006). Migration, minorities and multilingualism: Language ideologies in Europe. In P. Stevenson; C. Mar-Malinaro (Eds.), Language ideologies, practices and policies: Language and the future of Europe. Basingstoke: Springer, pp.13-27.

GALLOWAY, N.; ROSE, H. (2014). Introducing Global Englishes. London: Routledge.

GARCÍA, O. (2009). Education, multilingualism and translanguaging in the 21 st century. In A. Mohanty; M. Panda; M. R. Phillipson; T. Skutnabb-Kangas (Eds.), Multilingual education for social justice: Globalising the local. New Delhi: Orient Blackswan, pp.128-145.

GARCÍA, O., \& WEI, L. (2014). Translanguaging: Language, bilingualism and education. New York: Palgrave Macmillan.

GARCÍA, O. (2017). Translanguaging in schools: Subiendo y bajando, bajando y subiendo as afterword. Journal of Language, Identity and Education. v. $16 \mathrm{n}^{\circ} 4$, pp. 256-263.

GEE, J. P. (1996). Social linguistics and literacies (2nd ed.). London: Falmer Press.

GOFFMAN, E. (1981). Forms of talk. Philadelphia, PA: University of Pennsylvania Press.

GOTTI, M. (ed.). (2009). Commonality and individuality in academic discourse. Bern: Peter Lang.

GUNN, S. (2006). History and cultural theory. Harlow: Pearson Educated Limited.

GUTIÉRREZ, K. D. (2008). Developing a sociocritical literacy in the third space. Reading research quarterly, v. $43 \mathrm{n}^{\circ} 2$, pp. 148-164.

HALL, S. (1994). The question of cultural identity. In: Polity (ed.), The polity reader in cultural theory, Cambridge: Polity Press.

HARWOOD, N.; AUSTIN, L.; MACAULAY, R. (2012). Cleaner, helper, teacher? The role of proofreaders of student writing. Studies in Higher Education. v. $37 \mathrm{n}^{\circ}$ 5, pp. 569-584.

HEATH, S.; STREET, B. (2008). On ethnograpby: On approaches to language and literacy research. New York: Economic Policy Institute and Teachers College. 
HINDS, J. (1983). Contrastive rhetoric: Japanese and English. Text, v. 3 nº 2, pp. 183-195.

HINDS, J. (1990). Inductive, deductive, quasi-inductive: Expository writing in Japanese, Korean, Chinese, and Thai. In U. Connor; A. M. Johns (Eds.), Coberence in writing: Research and pedagogical perspectives. Alexandria, VA: TESOL, pp. 87-110.

HUNT, E., \& AGNOLI, F. (1991). The whorfian hypothesis: A cognitive psychology perspective. Psychological Review, v. 98 n³ , pp. 377-389.

HYLAND, K. (2006). English for academic purposes: An advanced resource book. Oxon: Routledge.

HYLAND, K. (2012). Disciplinary identities: Individuality and community in academic discourse. Cambridge, UK: Cambridge University Press.

HYLAND, K. (2018). Sympathy for the devil? A defence of EAP. Language Teaching. v. 51 n 3 , pp. 383-399.

IVANIČ, R. (1998). Writing and identity: The discoursal construction of identity in academic writing. Amsterdam: John Benjamins.

JENKINS, J. (2006). Current perspectives on teaching world Englishes and English as a lingua franca. TESOL Quarterly. v. $40 \mathrm{n}^{\mathrm{O}}$ 1, pp. 157-181.

JENKINS, J. (2014). English as a lingua franca in the international university: The politics of academic English language policy. London: Routledge.

KAPLAN, R. B. (1966). Cultural thought patterns in inter-cultural education. Language learning. v. $16 n^{\circ} 1-2$, pp. 1-20.

KAUFHOLD, K. (2015). Conventions in postgraduate academic writing: European students' negotiations of prior writing experience at an English speaking university. Journal of English for Academic Purposes. v. 20, pp. 125-134.

KOWAL, K. H. (1998). Rhetorical implications of linguistic relativity: Theory and application to Chinese and Taiwanese interlanguages. New York: Peter Lang.

KRESS, G. (2010). Multimodality: A social semiotic approach to contemporary communication: Routledge.

KUBOTA, R. (1997). A reevaluation of 11-12 transfer in writing among Japanese university students: Implications for contrastive rhetoric. Written Communication. v. $7 \mathrm{n}^{\mathrm{O}} 1$, pp. 69-100. 
KUBOTA, R.; LEHNER, A. (2004). Toward critical contrastive rhetoric. Journal of Second Language Writing. v. $13 \mathrm{n}^{\mathrm{o}} 1$, pp. 7-27.

KUBOTA, R.; LEHNER, A. (2005). Dialogue: Response to Ulla Connor's comments. Journal of Second Language Writing. v. 4, pp. 137-143.

LEA, M. (1998). Academic literacies and learning in higher education: constructing knowledge through texts and experience. Studies in the Education of Adults. v. $30 \mathrm{n}^{\mathrm{O}} 2$, pp. 156-171.

LEA, M. (2004). Academic literacies: A pedagogy for course design. Studies in Higher Education. v. $29 n^{\circ} 6$, pp. $739-756$.

LEA, M. (2008). Academic literacies in theory and practice. Encyclopedia of Language and Education. pp. 634-645.

LEA, M.; JONES, S. (2010). Digital literacies in higher education: Exploring textual and technological practice. Studies in Higher Education. v. 36 nº 4, pp. 377-393.

LEA, M.; STREET, B. (1998). Student writing in higher education: An academic literacies approach. Studies in Higher Education. v. 23 n 2, pp. 157-173.

LEA, M. R.; STREET, B. (2006). The "academic literacies" model: Theory and applications. Theory Into Practice. v. $45 \mathrm{n}^{\circ} 4$, pp. 368-377.

LEE, E., \& CANAGARAJAH, S. (2018). The connection between transcultural dispositions and translingual practices in academic writing. Journal of Multicultural Discourses, pp. 1-15.

LEVITT, P. (2011a). The transnational villagers. University of California Press.

LEVITT, P. (2011b). Transnational migration: taking stock and future directions. Global Networks. v. 1 n 3, pp. 195-216.

LEVITT, P.; GLICK SCHILLER, N. (2004). Conceptualizing simultaneity: A transnational social field perspective on society. International Migration Review. v. 38 $n^{\mathrm{o}} 145$, pp. 1002-1039.

LI, X. (2008). From contrastive rhetoric to intercultural rhetoric: A search for a collective identity. In U. Connor; E. Nagelhout; W. Rozycki (Eds.), Contrastive rbetoric: Reaching to intercultural rhetoric. Amsterdam: John Benjamins, pp. 11-24. 
LILLIS, T. (1997). New voices in academia? The regulative nature of academic writing conventions. Language and Education. v. 11 n 3 , pp. 182-199.

LILLIS, T. (2001). Student writing: access, regulation, desire. London: Routledge.

LILLIS, T. (2003). Student writing as 'academic literacies': Drawing on Bakhtin to move from critique to design. Language and Education. v. $17 \mathrm{n}^{\circ}$ 3, pp. 192-207.

LILLIS, T. (2006). 'Academic literacies' research as pedagogy: Dialogues of participation. In: GANOBSCIK-WILLIAMS, L. (ed.), Teaching academic writing in UK bigher education: Theories, practices, and models. Basingstoke, Hampshire: Palgrave.

LILLIS, T.; CURRY, M. J. (2010). Academic writing in a global context: The politics and practices of publishing in English. Oxon: Routledge.

LILLIS, T; HARRINGTON, K.; LEA, M; MITCHELL, S. (2016) Working with academic literacies: Case studies towards transformative practice. The WAC Clearinghouse/Parlor Press.

LILLIS, T.; SCOTT, M. (2007). Defining academic literacies research: Issues of epistemology, ideology and strategy. Journal of Applied Linguistics. v. $4 \mathrm{n}^{\mathrm{o}} 1$, pp. 5-32.

LILLIS, T.; TUCK, J. (2016). Academic literacies: A critical lens on writing and reading in the academy. In K. Hyland; P. Shaw (Eds.), The routledge handbook of English for academic purposes. Routledge: Routledge Handbooks, pp. 30-43.

MATSUDA, P. K. (2015). Identity in written discourse. Annual Review of Applied Linguistics. v. 35, pp. $140-159$.

MATSUDA, P. K. (2001). Voice in Japanese written discourse: Implications for second language writing. Journal of Second Language Writing. v. $10 \mathrm{n}^{\circ} 1-2$, pp. 35-53.

MATSUDA, P. K. (2003). Coming to voice: Publishing as a graduate student. In C. P. Casanave; S. Vandrick (Eds.), Writing for scholarly publication: Bebind the scenes in language education. Mahwah, NJ: Lawrence Erlbaum, pp. 39-51.

MATSUDA, P. K.; ATKINSON, D. (2008). Contrastive rhetoric: A conversation. In U. Connor; E. Nagelhout; W. Rozycki (Eds.), Contrastive rbetoric: Reaching to intercultural rhetoric. Amsterdam: John Benjamins, pp. 227-298.

MATSUDA, P. K.; TARDY, C. M. (2007). Voice in academic writing: The rhetorical construction of author identity in blind manuscript review. English for Specific Purposes, v. $26 \mathrm{n}^{\mathrm{O}} 2$, pp. 235-249. 
MAURANEN, A. (2012). Exploring EFL: Academic English shaped by non-native speakers. Cambridge: Cambridge University Press

MOTLHAKA, H. A.; MAKALELA, L. (2016). Translanguaging in an academic writing class: Implications for a dialogic pedagogy. Southern African Linguistics and Applied Languages Studies. v. $34 \mathrm{n}^{\mathrm{O}}$ 3, pp. 251-260.

NÍ CHONAILL, B. (2014). The linguistic challenges of immigration: The Irish higher education sector's response. In D. Little; C. Leung; P. Van Avermaet (Eds.), Managing diversity in education: Languages, policies, pedagogies: Mulitlingual Matters.

NORTON, B. (1997). Language, identity, and the ownership of English. TESOL Quarterly. V. $31 n^{\circ} 3$, pp. $409-429$.

PAVLENKO, A.; BLACKLEDGE, A. (2004). Negotiation of identities in multilingual contexts: Multilingual Matters.

PEDERSEN, A. (2010). Negotiating cultural identities through language: Academic English in Jordan. College Composition and Communication. v. 62 n 2, pp. 283-310.

PEIRCE, B. N. (1995). Social identity, investment, and language learning. TESOL Quarterly. v. $29 n^{\circ} 1$, pp. 9-31.

PENNYCOOK, A. (2001). Critical applied linguistics: A critical introduction. Mahwah, USA: Erlbaum Associates.

PENNYCOOK, A. (2007). Global Englishes and transcultural flows. New York: Routledge.

PRATT, M. L. (1992). Imperial eyes: Travel writing and transculturation. London: Routledge.

PRIOR, P. (2001). Voices in text, mind, and society: Sociohistoric accounts of discourse acquisition and use. Journal of Second Language Writing. v. $10 \mathrm{n}^{\mathrm{o}} 1-2$, pp. 55-81.

RISAGER, K. (2006). Language and culture: Global flows and local complexity. Buffalo: Multilingual Matters.

ROGER, R. (ed.) (2011). An introduction to critical discourse analysis in education. Routledge.

SMYTH, E. (2018). Widening access to higher education: Balancing supply and demand in Ireland. In S. Riddell; S. Minty; E. Weedon; S. Whittaker (Eds.), Higher education funding and access in international perspective (great debates in bigher education, volume): Emerald Publishing Limited, pp. 121-142. 
STREET, B. (1993). Cross-cultural approaches to literacy. Cambridge, UK: Cambridge University Press.

STREET, B. (2015). Academic writing: Theory and practice. Journal of Educational Issues. v. 12 $\mathrm{n}^{\mathrm{o}}$, pp. $110-116$.

TURNER, J. (2004). Language as academic purpose. Journal of English for Academic Purposes. v. $3 \mathrm{n}^{\mathrm{O}} 2, \mathrm{pp} .95-109$.

TURNER, J. (2012). Academic literacies: Providing a space for the socio-political dynamics of EAP. Journal of English for Academic Purposes. v. $11 \mathrm{n}^{\mathrm{0}}$ 1, pp. 17-25.

UYSAL, H. H. (2008). Tracing the culture behind writing: Rhetorical patterns and bidirectional transfer in L1 and L2 essays of Turkish writers in relation to educational context. Journal of Second Language Writing. v. $17 \mathrm{n}^{\mathrm{o}} 3$, pp. 183-207.

WILLIAMS, B. (2006). Pay attention to the man behind the curtain: The importance of identity in academic writing. Journal of Adolescent \& Adult Literacy. v. 49 n 8, pp. 710715 .

WINGATE, U. (2018). Academic literacy across the curriculum: Towards a collaborative instructional approach. Language Teaching. v. $51 \mathrm{n}^{\mathrm{O}} 3$, pp. 349-364.

ZAMEL, V. (1997). Toward a model of transculturation. TESOL Quarterly. v. $31 \mathrm{n}^{\mathrm{O}}$ 2, pp. $341-352$.

Recebido: 22/11/2018

Aceito: 10/03/2019

Publicado: 29/03/2019 